\title{
ANTIDEPRESSANT DRUGS: HIGHLY SENSITIVE AND VALIDATED SPECTROPHOTOMETRIC TECHNIQUE
}

\author{
H N DEEPAKUMARI ${ }^{1}$, M K PRASHANTH² AND H D REVANASIDDAPPA * *
}

\author{
${ }^{1}$ Department of Chemistry, Bharathi College, Bharathinagara, Mandya-571 401, India \\ ${ }^{2}$ Department of Chemistry, University of Mysore, Manasagangotri, Mysore-570 006, India
}

(Received: September 26, 2013 - Accepted: March 25, 2014)

\begin{abstract}
A simple, rapid, selective and highly sensitive spectrophotometric method is described for the quantitative determination of the tricyclic antidepressant drugs, desipramine hydrochloride (DPH), clomipramine hydrochloride (CPH) and imipramine hydrochloride (IMH) in pure and in pharmaceutical preparations. The proposed method is based on the bromination of above drugs with known excess of bromine. The unreacted bromine is determined based on its ability to bleach the dye Eiochrome blue black R quantitatively at $530 \mathrm{~nm}$ for all the three drugs obeying Beer's law in the range, $0.0-8,0.0-10$ and $0.0-9.0 \mu \mathrm{g} \mathrm{ml}{ }^{-1}$ for DPH, $\mathrm{CPH}$ and IMH, respectively. The molar absorptivity values were found to be $1.61 \times 10^{4}, 1.62 \times 10^{4}$ and $1.57 \times 10^{4} 1 \mathrm{~mol}^{-1} \mathrm{~cm}^{-1}$, respectively with the corresponding Sandell's sensitivity values $0.0187,0.0216$ and $0.0202 \mathbf{\mu g ~ s m}^{-2}$. The limits of detection and (LOD) and quantification (LOQ) are also reported for the developed method. Intra- and inter-day precision and accuracy of the method were established according to the current ICH guidelines. Applications of the procedure to the analysis of various pharmaceutical preparations gave reproducible and accurate results. Further, the validity of the procedure was confirmed by applying the standard addition technique and the results were evaluated in terms of Student's $t$-test and variance ratio $F$-test to find out the significance of proposed method over the reference method.
\end{abstract}

Keywords: Eriochrome blue black R, antidepressant drugs, desipramine hydrochloride, clomipramine hydrochloride, imipramine hydrochloride, unreacted bromine.

\section{INTRODUCTION}

$\mathrm{DPH}, \mathrm{CPH}$ and IMH are tricyclic antidepressants. Desipramine hydrochloride (DPH), is chemically known as [3-(10,11-Dihydro-dibenzo[b,f] azepin-5-yl)-propyl]-methyl-amine hydrochloride (Fig 1. a). It inhibits the reuptake of norepinephrine and to a lesser extent serotonin. It is used to treat depression, but not considered a first line treatment since the introduction of Selective serotonin re-uptake inhibitors (SSRI) antidepressants. It is the active in vivo metabolite of imipramine and as such, shares many of imipramine's pharmacologic effects. Chemically, clomipramine hydrochloride $(\mathrm{CPH})$ is 3-(3-chloro-10,11-dihydro-5H-dibenzo[b,f]azepin-5-yl)-N,N-dimethylpropan1-aminehydrochloride (Fig. 1. b). Clomipramine is used for the treatment and relief of obsessive and compulsive disorders as well as in depression and other emotional disturbances. In spite of new atypical drugs such as those of the SSRI group (fluoxetine, fluvoxamine etc), clomipramine is still the reference compound in the treatment of these psychiatric disorders [1-3]. Chemically, imipramine hydrochloride (IMH) is (10,11-Dihydro-N,N-dimethyl)-5Hdibenz $[\mathrm{b}, \mathrm{f}]$ azepine-5-propanamine hydrochloride (Fig. 1. c). It is a potent inhibitor of noradrenaline reuptake at noradrenergic nerve endings. All the three drugs DPH, CPH and IMH are official in European Pharmacopoeia [4, 5, 6]. The report describes a potentiometric titration of DPH, $\mathrm{CPH}$ and IMH using $0.1 \mathrm{M}$ sodium hydroxide as titrant in acidic medium.

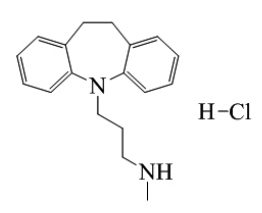

(a)

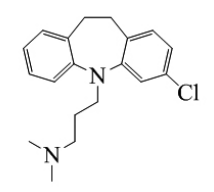

(b)

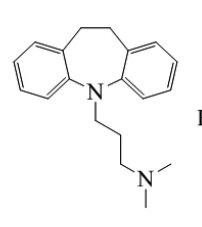

(c)
Several analytical methods are available in the literature for the determination of DPH, CPH and IMH in biological fluids and/or pharmaceutical formulations. These methods include chromatographic techniques like HPLC-DAD method using 7,7,8,8-tetracyano-quinodimethane (TCNQ) as a derivatisation agent [7], HPLC with liquid-liquid micro extraction technique [8], RP-HPLC and HPTLC [9] GC [10], GC-MS [11-13,], electrogenerated chemiluminescence $[14$,$] , voltammetry [15], spectrofluorimetry [16] and$ spectrophotometry [17-27].

The above reported analytical methods suffer from one or the other disadvantages. The reported chromatographic techniques [7-13] require expensive experimental set-up, requires sophisticated instrumentation [15] and involvement of scrupulous experimental conditions which are not affordable in every laboratory for routine analysis; Whereas the reported spectrophotometric methods were associated with some major drawbacks such as, lesser sensitivity [16-17, 23-26], tedious extraction procedures [16-17, 26], maintenance of strict experimental conditions $[16,17,21]$ and time consuming $[18,20,27]$. For these reasons, the development of a new, simple, rapid, selective, sensitive and inexpensive spectrophotometric method that overcomes the drawbacks of the existing methodologies was very essential.

Comparison between the reported spectrophotometric methods for determination of DPH, CPH and IMH with the proposed method is shown in Table 1.

The method suggested is devoted to study a highly sensitive, selective, reproducible and economically viable method that could be used to determine $\mathrm{DPH}, \mathrm{CPH}$ and IMH in bulk drug and in dosage forms. The proposed method employs the use of bromate-bromide solution and Eriochrome blue black R as reagents and is based on the bromination of above drugs with known excess of bromine followed by reaction with Eriochrome blue black R to produce violet colored dye. The linearity, accuracy, precision, ruggedness and recovery of the assay were validated according to ICH guidelines. The method is suitable for routine analytical use, as it is simple and does not involve any complicated extraction procedures and was found to be simple, selective and cost-effective compared too many reported methods.

Fig. 1-Structure of (a) DPH, (b) CPH and (c) IMH. 
Table 1-Comparison of the performance characteristics of the proposed method with the existing visible spectrophotometric/chromatographic methods.

\begin{tabular}{|c|c|c|c|c|c|}
\hline Sl. No. & Reagent's used & Methodology & $\begin{array}{l}\text { Linear } \\
\text { range, } \\
\mu \mathrm{g} \mathrm{ml}^{-1}\end{array}$ & Remarks & Ref \\
\hline 1 & Alizarin red S & $\begin{array}{l}\text { The ion-pair complex showed maximum fluorescence } \\
\text { intensity at } 561 \mathrm{~nm} \text { with excitation at } 490 \mathrm{~nm}\end{array}$ & $1-20$ & $\begin{array}{l}\text { Requires extraction procedure } \\
\text { and maintenance of strict } \mathrm{pH} \\
\text { control }\end{array}$ & 16 \\
\hline 2 & $\begin{array}{l}\text { Molybdenum(V) } \\
\text { thiocyanate and hexa kis } \\
\text { iron (III) solution }\end{array}$ & $\begin{array}{l}\text { Ion-pair formation between molybdenum (V) } \\
\text { thiocyanate and hexa kis iron (III) solution }\end{array}$ & $10-200$ & $\begin{array}{l}\text { Less sensitive and requires } \\
\text { extraction procedure }\end{array}$ & 17 \\
\hline 4 & $\begin{array}{l}p \text {-phenylenediamine } \\
\text { dihydrochloride }\end{array}$ & $\begin{array}{l}\text { Formation of diazotized } p \text {-phenylenediamine } \\
\text { dihydrochloride, shows maximum absorption at } 565 \\
\mathrm{~nm}\end{array}$ & $1.1-3.6$ & $\begin{array}{l}\text { Sensitive but requires high } \\
\text { acidic conditions and cooling } \\
\text { to } 0 \text { to } 5^{\circ} \mathrm{C}\end{array}$ & 19 \\
\hline 7 & $\mathrm{NaClO}_{4}$-buffer-ethanol & derivative spectrophotometry & $0.63-10.04$ & $\begin{array}{l}\text { Sensitive but of lack of } \\
\text { selectivity }\end{array}$ & 22 \\
\hline 8 & Methyl orange & $\begin{array}{l}\text { Formation of ion-pair with methyl orange and the } \\
\text { absorbance was measured at } 425 \mathrm{~nm}\end{array}$ & $0.79-25.3$ & Less sensitive & 23 \\
\hline 9 & eriochrome cyanine $\mathrm{R}$ & $\begin{array}{l}\text { Reacts in neutral medium with imipramine forming } \\
\text { reddish compound }\end{array}$ & $10-80$ & Less sensitive & 24 \\
\hline 10 & $\begin{array}{l}\text { Iminodibenzyl } \\
\text { p-chloranilic acid }\end{array}$ & $\begin{array}{l}\text { First derivative of ratio spectra } \\
\text { Formation of charge transfer complex }\end{array}$ & $\begin{array}{l}5-30 \\
20-200\end{array}$ & Less sensitive & 25 \\
\hline 11 & $\begin{array}{l}\text { azocarmine } \mathrm{G}(\mathrm{ACG}) \\
\text { naphthalene blue (NB) } \\
\text { woolfast blue BL (WFB } \\
\text { BL) }\end{array}$ & $\begin{array}{l}\text { Formed ion-associates exhibit absorption maxima at } \\
550 \mathrm{~nm}(\mathrm{ACG}) \\
620 \mathrm{~nm}(\mathrm{NB}) \text { and } \\
590 \mathrm{~nm} \text { (WFB BL) }\end{array}$ & $\begin{array}{l}2.0-12.0 \\
4.0-16.0 \\
1.0-12.0\end{array}$ & $\begin{array}{l}\text { Less sensitive and requires } \\
\text { extraction procedures }\end{array}$ & 26 \\
\hline
\end{tabular}

\section{EXPERIMENTAL SECTION}

Apparatus

All the absorbance measurements were performed using a Systronics Model 166 digital spectrophotometer provided with 1-cm matched quartz cells.

\section{Reagents and Standards}

Analytical reagent grade chemicals were used, and double distilled water was used throughout the experiment to prepare all solutions.

i.

Standard DPH, CPH and IMH solutions. Pure samples (99.95\%) of DPH, CPH and IMH were used and received as gift from La Pharma, Ahmedabad, Gujarat, India, and Aventis Pharma. Ltd., Mumbai, India. A stock standard solutions equivalent to $100 \mu \mathrm{g}$ $\mathrm{ml}^{-1}$ of the cited drugs was prepared separately by dissolving $10 \mathrm{mg}$ of the pure drug in $100 \mathrm{ml}$ distilled water. Working solutions were prepared as required by dilution in water.

Pharmaceutical formulations of DPH such as Norpramin and Pertofrane (Aventis Pharmaceuticals), CPH such as Ocifril (La Pharma) and Clonil (Intas) and Impramine (Sun) and Depranil (La Pharma) tablets were purchased from local commercial sources.

ii.

Bromate-Bromide solution $(10 \mu \mathrm{g}$ $\left.\mathrm{ml}^{-1}\right)$. A stock standard solution of $100 \mu \mathrm{g} \mathrm{ml^{-1 }}$ bromate solution for bromine generation was prepared by dissolving accurately weighed $0.05 \mathrm{~g}$ of potassium bromate (Sarabhai M. Chemicals, India) and $0.5 \mathrm{~g}$ of potassium bromide (S. D.
Fine Chem., India) in water and diluted to the mark in a $500 \mathrm{ml}$ calibrated flask. To get $20 \mu \mathrm{g} \mathrm{ml}^{-1}$ of $\mathrm{KBrO}_{3}$ stock solution, $20 \mathrm{ml}$ of bromate-bromide mixture was diluted to $100 \mathrm{ml}$ in distilled water. Then, $50 \mathrm{ml}$ of this stock solution was transferred in to a $100 \mathrm{ml}$ calibrated flask containing $40 \mathrm{ml}$ of $4.25 \mathrm{M} \mathrm{H}_{2} \mathrm{SO}_{4}$ and diluted to $100 \mathrm{ml}$ with water to get the working concentration of $10 \mu \mathrm{g}$ $\mathrm{ml}^{-1}$ of $\mathrm{KBrO}_{3}$. This bromate solution $\left(10 \mu \mathrm{g} \mathrm{ml}^{-1}\right)$ was freshly prepared on the day of use.

iii.

Erio chrome blue black R (EBBR)

$(0.1 \%, w / v)$. It was prepared by dissolving $0.1 \mathrm{~g}$ of Erio chrome blue black R (BDH chemicals, Poole, England) in $100 \mathrm{ml}$ water to get $0.1 \%$ solution.

\section{General procedures}

\section{Calibration curve}

Appropriate aliquots of aqueous working solution containing $0.0,0.25,0.5$, $1.0, \ldots .4 .0 \mathrm{ml}$ of DPH $\left(20 \mu \mathrm{g} \mathrm{ml}{ }^{-1}\right), 0.0,0.25,0.5,1.0, \ldots .5 .0 \mathrm{ml}\left(20 \mu \mathrm{g} \mathrm{ml}^{-1}\right)$ of CPH and $0.0,0.05,0.125,0.25,0.5,1.0,1.5,2.0$ and $2.25 \mathrm{ml}$ of IMH $(40 \mu \mathrm{g}$ $\mathrm{ml}^{-1}$ ) were transferred into a series of separate $10 \mathrm{ml}$ calibrated flasks using a micro burette. To each flask were added $6 \mathrm{ml}$ of bromate-bromide mixture $(10$ $\mu \mathrm{g} \mathrm{ml}^{-1}$ w.r.t $\mathrm{KBrO}_{3}$ ), and the flasks were stoppered. Finally, $0.75 \mathrm{ml}$ of $0.1 \%$ EBBR was added to each flask and mixed well before being diluted to $10 \mathrm{ml}$ with distilled water and the absorbance of the bright pink color solution (violet) was measured at $530 \mathrm{~nm}$ against the reagent blank. The reagent blank was prepared similarly, but without drug content. 
The amount of the each drug present in the respective samples was computed from the concurrent calibration curve or the regression equation. All measurements were made at room temperature $\left(27 \pm 3{ }^{\circ} \mathrm{C}\right)$.

Procedure for commercial samples

The applicability of the proposed method for the determination of the above cited drugs was tested using two brands of each tablet in pharmaceutical formulation. For this purpose, twenty tablets of DPH $(25 \mathrm{mg}$ and $50 \mathrm{mg}$ ), CPH (10 and $25 \mathrm{mg}$ ) and IMH (20 mg) were weighed accurately and ground into fine powder. An amount of the powder equivalent to $10 \mathrm{mg}$ of each drug was weighed accurately into a three separate $100 \mathrm{ml}$ calibrated flasks and 50 $\mathrm{ml}$ distilled water was added. The content was shaken for about $30 \mathrm{~min}$; the volume was diluted to the mark with water and mixed well and filtered using a Whatman No.41 filter paper. The filtrate containing the cited drugs were at a concentration $100 \mu \mathrm{g} \mathrm{ml}^{-1}$ was subjected to analysis by the procedure described above after suitable dilution step.

Analysis of placebo blank

A placebo blank of the composition: talc $(15 \mathrm{mg})$, acacia $(10 \mathrm{mg})$, starch $(15 \mathrm{mg})$, methyl cellulose $(20 \mathrm{mg})$, sodium citrate $(25 \mathrm{mg})$, magnesium stearate $(20 \mathrm{mg})$ and sodium alginate $(15 \mathrm{mg}$ ) was made and its solution was prepared in $50 \mathrm{ml}$ calibration flask as described under 'Procedure for commercial samples', and then subjected to analysis using the procedure described under 'Procedure for Calibration curve'.

\section{Analysis of Synthetic mixture}

To the placebo blank of the composition described above, $10 \mathrm{mg}$ each of DPH and CPH was added into a separate $100 \mathrm{ml}$ calibrated flasks and homogenized, and the solution was prepared as described under 'Procedure for commercial samples', and then subjected to analysis by the procedure described under 'Procedure for Calibration curve'. The analysis was used to study the interferences of excipients such as talc, acacia, starch, methyl cellulose, sodium citrate, sodium alginate and magnesium stearate.

\section{RESULTS AND DISCUSSION}

\section{Chemistry of the method}

Bromate in acid medium acts as an oxidizing agent [28]. Preliminary experiments revealed that $\mathrm{DPH}, \mathrm{CPH}$ and IMH drugs are prone to bromination reaction by bromine generated in situ by the action of acid on bromate-bromide mixture.

In the present study, a known excess of bromine is used to brominate the studied drugs (DPH, CPH and IMH) in an acidic condition. The unreacted bromine bleaches the color of the azo-dye, EBBR, thereby a decrease in bromine concentration. This reaction formed the basis of DPH, CPH and IMH determination. When EBBR is bleached (brominated) completely with bromine, the absorbance at $530 \mathrm{~nm}$ decreases and reaches minimum value. In the presence of drug concentration (DPH, CPH and IMH), bromine is reduced to bromide and the unreacted bromine decolorized the EBBR. Thus, with increasing concentration of drug, higher amount of bromine is reduced and this is observed by a linear increase in the absorbance due to the unbleached EBBR at $530 \mathrm{~nm}$.

The difference in concentration of unbleached EBBR and the reacted bromine in the reaction mixture give the exact concentration of the drug. The absorption spectra [Fig. 2] show that, a linear increase in absorbance with increasing drug concentration. The possible reaction pathway is given in Scheme 1.

$$
\text { Drug }+ \text { Known excess of } \mathrm{B}_{\mathrm{r} 2} \longrightarrow 3 \mathrm{BrO}_{2}+3 \mathrm{H}_{2} \mathrm{O}
$$

Scheme 1-Proposed reaction scheme.

\section{Absorption spectra}

EBBR has a maximum absorbance at $530 \mathrm{~nm}$ (Curve A). On treatment with bromine, the color of the EBBR bleaches due to bromination. When EBBR is bleached completely with bromine, the absorbance at $530 \mathrm{~nm}$ decreases and reaches minimum value (Curve B). With an increase in drug concentration (DPH/CPH/ IMH), there is a corresponding decrease in bromine concentration, and as a result less brominated/bleached EBBR is obtained (Curves C, D and E). Here, DPH is used as a model compound, since CPH/IMH is also behaved similarly to it. The concentration of bromine, EBBR and the DPH are given in Fig. 2

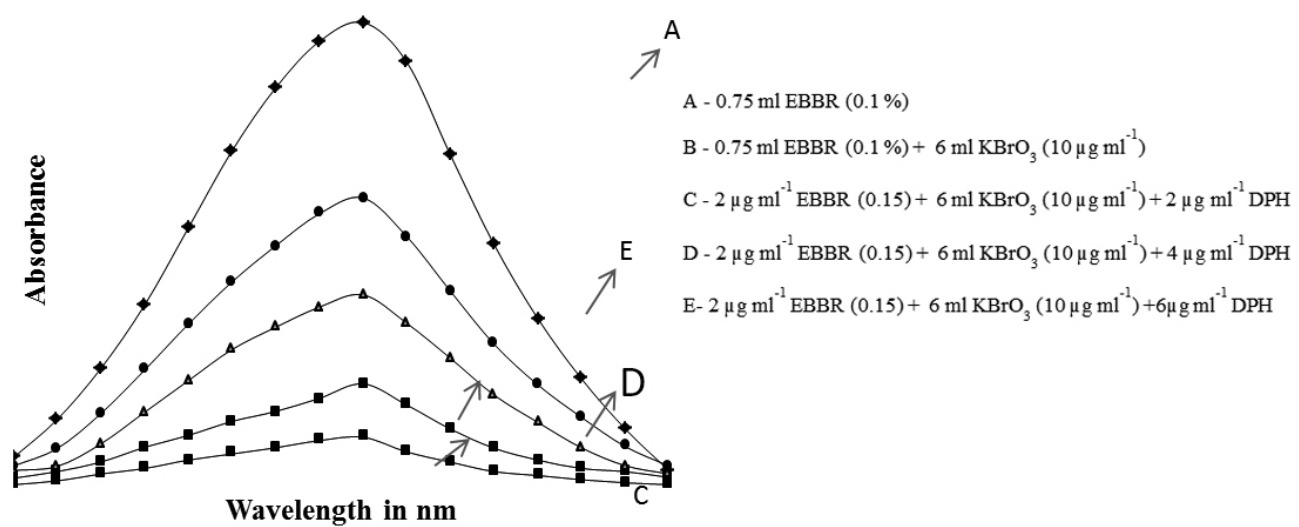

Fig. 2-Absorption spectra for DPH. 
Optimization of variables and method development

The factors affecting reaction conditions (effect of dye, bromine concentration and standing time) were studied separately by measuring the absorbance of the brominated products at $530 \mathrm{~nm}$ for both the drugs such as $\mathrm{DPH}, \mathrm{CPH}$ and $\mathrm{IMH}$, respectively by varying one parameter at a time and keeping the others constant.

Effect of dye and reagent concentration

In spectrophotometric analytical methods where maximum sensitivity is desired, the reagent concentration in solution is an important parameter to be studied. In order to achieve this objective, preliminary experiment was performed to fix the upper and lower limits of the dye that could be determined spectrophotometrically at $530 \mathrm{~nm}$. The upper limit was of the absorbance (0.728) adjusted was obtained by the addition of $0.75 \mathrm{ml}$ of $0.1 \%$ EBBR in 10 $\mathrm{ml}$ of the reaction mixture. The lower limits of the absorbance was reached by the addition of $6 \mathrm{ml}$ of bromate-bromide mixture $\left(10 \mu \mathrm{g} \mathrm{ml}^{-1} \mathrm{~W} \mathrm{r}\right.$. t. $\left.\mathrm{KBrO}_{3}\right)$ in the same volume. The absorbances of these are given in Fig.2.

\section{Reaction Time and Color Stability}

Experiment was carried out to optimize the reaction time and stability of the substituted product formed. The effect of reaction time between the drugs (DPH, CPH and IMH) and the bromine generated in situ was completed in 3 min (Fig. 2, Curves C, D and E). After completion of the reaction between the drug and the bromine, a 5 min standing time was necessary for the complete bleaching of the dye color by the residual bromine and this bromination process was instantaneous and found to be complete within $8 \mathrm{~min}$. The absorbance of the measured species was stable up to $30 \mathrm{~min}$.

\section{Method validation}

The spectrophotometric method validation characteristics were tested in accordance with ICH [29] guidelines. The proposed method was evaluated under the optimum conditions with respect to linearity, accuracy, precision, molar absorptivity, Sandell's sensitivity and Student's $t$ - and $F$-test.

Linearity

A linear calibration graph was constructed using the standard solutions of DPH, CPH and IMH. Under established experimental conditions, a linear correlation was found between the absorbance at $530 \mathrm{~nm}$ and concentrations of $\mathrm{DPH}, \mathrm{CPH}$ and IMH in the ranges are given in Table 2. Regression analysis of the calibration curves are described by the equation:

$$
y=\mathrm{a}+\mathrm{b} x
$$

where $y=$ absorbance, $\mathrm{a}=$ intercept, $\mathrm{b}=$ slope and $x=$ concentration and the values are presented in Table 2. The optical characteristics such as absorption maxima, Beer's law limit, molar absorptivity and Sandell's sensitivity values [30] are also given in Table 2. The calibration curves are shown in Figures 3. $\mathrm{a}, \mathrm{b}$ and $\mathrm{c}$, respectively.

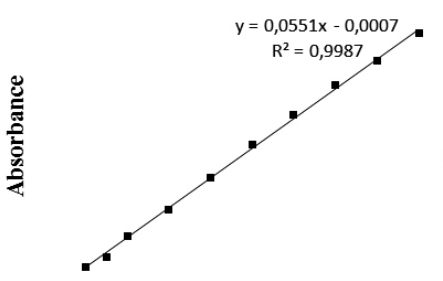

conc. in $\mu \mathrm{g} \mathrm{ml}^{-1}$

(a)

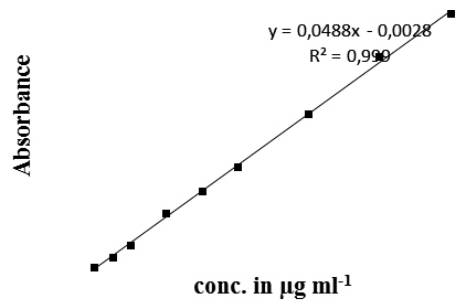

(b)

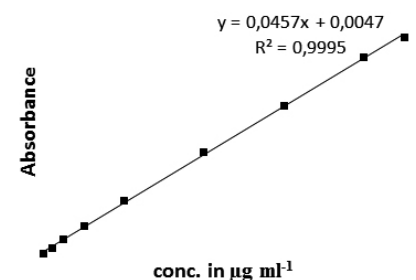

(c)

Fig. 3-Calibration curves for (a) DPH, (b) $\mathrm{CPH}$ and (c) $\mathrm{CPH}$.
Sensitivity

The detection limits (LOD) and limits of quantitation (LOQ), for the proposed method was also evaluated as per ICH guidelines using the formula: where $\sigma$ is the standard deviation of replicate determination values under the same conditions as for the sample analysis in the absence of the analyte, and $s$ is the slope of the calibration graph. The high values of molar absorptivity $(\varepsilon)$ and low values of Sandell's sensitivity and LOD indicate the high sensitivity of the proposed method (Table 2).

$$
\mathrm{LOD}=\frac{3.3 \times \sigma}{s} \text { and } \mathrm{LOQ}=\frac{10 \times \sigma}{s}
$$

\begin{tabular}{|c|c|c|c|}
\hline Parameter & DPH & CPH & IMH \\
\hline$\lambda_{\max } \mathrm{nm}$ & 530 & 530 & 530 \\
\hline $\begin{array}{l}\text { Beer's law range } \\
\quad\left(\mu \mathrm{g} \mathrm{ml}^{-1}\right)\end{array}$ & $0.0-8$ & $0.0-10$ & $0.0-9.0$ \\
\hline Linear range $\left(\mu \mathrm{g} \mathrm{ml}^{-1}\right)$ & $0.3-8$ & $0.5-10$ & $0.3-9.0$ \\
\hline $\begin{array}{l}\text { Molar absorptivity }(\varepsilon) \\
\qquad\left(1 \mathrm{~mol}^{-1} \mathrm{~cm}^{-1}\right)\end{array}$ & $1.624 \times 10^{4}$ & $1.615 \times 10^{4}$ & $1.572 \times 10^{4}$ \\
\hline $\begin{array}{l}\text { Sandell's sensitivity } \\
\left(\mu \mathrm{g} \mathrm{cm}^{-2}\right)\end{array}$ & 0.0187 & 0.0217 & 0.0202 \\
\hline $\begin{array}{c}\text { Regression equation, } \mathrm{Y}^{*} \\
\text { Intercept (a) } \\
\text { Slope (b) }\end{array}$ & $\begin{array}{l}-0.0023 \\
0.0559\end{array}$ & $\begin{array}{c}-0.0028 \\
0.0488\end{array}$ & $\begin{array}{l}0.0047 \\
0.0457\end{array}$ \\
\hline $\begin{array}{l}\text { Correlation coefficient } \\
\text { (r) }\end{array}$ & 0.999 & 0.999 & 0.9996 \\
\hline $\mathrm{S}_{\mathrm{a}}$ & 0.0375 & 0.0009 & 0.0060 \\
\hline $\mathrm{S}_{\mathrm{b}}$ & 0.0061 & 0.0199 & 0.0006 \\
\hline LOQ $\left(\mu \mathrm{g} \mathrm{ml}^{-1}\right)$ & 0.2125 & 0.1018 & 0.2151 \\
\hline $\operatorname{LOD}\left(\mu \mathrm{g} \mathrm{ml}^{-1}\right)$ & 0.0701 & 0.0336 & 0.0709 \\
\hline
\end{tabular}

Table 2-Analytical and regression parameters of the proposed method.

$* \mathrm{y}=\mathrm{a}+\mathrm{bx}$, where $\mathrm{x}$ is the concentration of $\mathrm{DPH}, \mathrm{CPH}$ and $\mathrm{IMH}$ in $\mu \mathrm{g} \mathrm{ml}{ }^{-1}$ and $\mathrm{y}$ is the absorbance at the respective $\lambda_{\max }, \mathrm{S}_{\mathrm{a}}$ is the standard deviation of the intercept, $\mathrm{S}_{\mathrm{b}}$ is the standard deviation of the slope.

\section{Intra-day and Inter-day precision and accuracy}

In order to determine the accuracy and precision (intra- and inter-day) of the proposed method, solutions containing three different concentrations (low, medium and high) (Table 3 ) within the working limits of drugs were prepared and analyzed in five replicates in the same day (intra-day precision) and in after 3 days (inter-day precision). The relative error, RE (\%) and relative standard deviation, RSD (\%) values of both intra and inter-day studies were satisfactory and showed that the best appraisal of the procedure in daily use.

\section{Interferences}

The selectivity of the proposed method to pharmaceutical samples was tested by a systematic study under the optimum experimental conditions which were made for the effect of the additives and excipients. The recommended procedure was applied to the analysis of both placebo blank and synthetic mixtures prepared in the laboratory as described under Analysis of placebo blank and Synthetic mixture. The usual diluents and excipients such as starch sodium alginate, talc, gelatin, dextrose, methyl cellulose and acacia were found not to interfere with the analysis by the proposed method and the results were obtained in the range $98.5 \%$ to $101 \%$ for $\mathrm{DPH}, \mathrm{CPH}$ and $\mathrm{IMH}$, respectively. These results further showed clearly the accuracy and precision of the developed method.

\section{Application to analysis of pharmaceutical samples}

To check the validity of the proposed method, the drugs under investigation (DPH, CPH and IMH) was determined in some commercial formulations and the results are presented in Table 4 . The results of an assay of the cited drugs were statistically compared with the reference method $[19,24]$ by applying the Student's $t$ - test for accuracy and $F$-test for precision. The results in the Table 
4 showed that there is no significant difference between the proposed and reference methods $[19,24]$ at the $95 \%$ confidence level with respect to accuracy and precision. The calculated $t$ - and $F$-values (Table 4 ) did not exceed the tabulated values $(\mathrm{t}=2.77$ and $\mathrm{F}=6.39)$, they could therefore be used easily for the routine analysis of pure $\mathrm{DPH}, \mathrm{CPH}$ and IMH in its dosage forms.

The results obtained are presented in Table 3 and show that the accuracy and precision of the proposed method have good repeatability and reproducibility.

Table 3-Evaluation of intra-day and inter-day accuracy and precision.

\begin{tabular}{|c|c|c|c|c|c|c|c|}
\hline \multirow{2}{*}{ Drug } & \multirow{2}{*}{$\begin{array}{c}\text { Drug } \\
\text { added, } \\
\mu \mathrm{g} \mathrm{ml}^{-1}\end{array}$} & \multicolumn{3}{|c|}{ Intra-day accuracy and precision $(n=5)$} & \multicolumn{3}{|c|}{$\begin{array}{l}\text { Inter-day accuracy and precision } \\
\qquad(\mathrm{n}=5)\end{array}$} \\
\hline & & $\begin{array}{l}\text { Drug found, } \\
\mu \mathrm{g} \mathrm{m}^{-1}\end{array}$ & $\% \mathrm{RE}$ & $\%$ RSD & $\begin{array}{l}\text { Drug found, } \\
\mu \mathrm{g} \mathrm{ml}^{-1}\end{array}$ & $\% \mathrm{RE}$ & $\%$ RSD \\
\hline \multirow{3}{*}{$\mathrm{CPH}$} & 0.4 & 0.393 & 1.79 & 1.32 & 0.408 & 1.89 & 1.29 \\
\hline & 0.8 & 0.786 & 1.78 & 1.54 & 0.813 & 1.67 & 1.28 \\
\hline & 1.2 & 1.204 & 0.36 & 1.89 & 1.210 & 0.80 & 2.04 \\
\hline \multirow{3}{*}{ DPH } & 0.4 & 0.395 & 1.28 & 1.05 & 0.41 & 2.28 & 1.79 \\
\hline & 0.6 & 0.592 & 1.41 & 1.17 & 0.62 & 2.97 & 2.04 \\
\hline & 0.8 & 0.782 & 2.31 & 1.58 & 0.82 & 2.97 & 2.42 \\
\hline \multirow{3}{*}{ IMH } & 2 & 1.96 & 1.19 & 0.77 & 2.03 & -1.64 & 2.79 \\
\hline & 4 & 3.97 & 1.23 & 1.42 & 4.04 & -0.88 & 2.08 \\
\hline & 6 & 5.92 & 1.30 & 1.59 & 5.97 & 0.55 & 2.25 \\
\hline
\end{tabular}

$\%$ RE: percent Relative error; \% RSD: percent Relative standard deviation.

Table 4-Results of determination of DPH and CPH in dosage form and statistical comparison with the reference method.

\begin{tabular}{|c|c|c|c|c|}
\hline \multirow{2}{*}{$\begin{array}{l}\text { Drug } \\
\text { studied }\end{array}$} & \multirow{2}{*}{$\begin{array}{l}\text { Tablet brand } \\
\text { Name* }\end{array}$} & \multirow{2}{*}{$\begin{array}{l}\text { Nominal amount mg per } \\
\text { tablet }\end{array}$} & \multicolumn{2}{|c|}{ Found $* *(\%$ of nominal amount $\pm \mathrm{SD})$} \\
\hline & & & Reference Method [17] & Proposed method \\
\hline \multirow{2}{*}{ DPH } & Norpramin $^{\mathrm{a}}$ & $25 \mathrm{mg}$ & $99.9 \pm 1.14$ & $\begin{array}{c}100.20 \pm 0.112 \\
\mathrm{t}=1.26, \mathrm{~F}=5.36\end{array}$ \\
\hline & Pertofrane $^{\mathrm{b}}$ & $50 \mathrm{mg}$ & $100.2 \pm 0.15$ & $\begin{array}{c}100.54 \pm 0.11 \\
\mathrm{t}=1.98, \mathrm{~F}=1.58\end{array}$ \\
\hline \multirow{2}{*}{$\mathrm{CPH}$} & Ocifril $^{c}$ & $25 \mathrm{mg}$ & $99.8 \pm 0.78$ & $\begin{array}{c}100.41 \pm 0.120 \\
\mathrm{t}=2.43, \mathrm{~F}=5.48\end{array}$ \\
\hline & Clonil $^{\mathrm{d}}$ & $10 \mathrm{mg}$ & $100.5 \pm 0.21$ & $\begin{array}{c}100.57 \pm 0.126 \\
\mathrm{t}=0.41, \mathrm{~F}=2.79\end{array}$ \\
\hline \multirow{2}{*}{$\mathrm{IMH}$} & Impramine $^{e}$ & $25 \mathrm{mg}$ & $99.68 \pm 0.20$ & $\begin{array}{c}99.87 \pm 0.29 \\
\mathrm{t}=0.61, \mathrm{~F}=0.46\end{array}$ \\
\hline & Depranil $^{\mathrm{f}}$ & $25 \mathrm{mg}$ & $99.55 \pm 0.25$ & $\begin{array}{c}100.89 \pm 0.17 \\
\mathrm{t}=1.49, \mathrm{~F}=2.21\end{array}$ \\
\hline
\end{tabular}

*Marketed by: a and b. (Aventis Pharmaceuticals), c. (La Pharma), d. (Intas), e. (Sun), and f. (La Pharma)

**Mean value of five determinations

Tabulated $t$ - and $F$-values at $95 \%$ confidence level are 2.77 and 6.39 , respectively.

Evaluation of accuracy by recovery study (standard addition technique)

To further assess the accuracy of the proposed method, recovery experiment was performed by applying the standard addition technique. The recovery test was done by adding the drugs (DPH, $\mathrm{CPH}$ and IMH) to the previously analyzed tablets. The recovery of each drug was calculated by comparing the concentration obtained from the spiked mixtures with those of pure drugs. The recovery of the pure drug added was quantitative and the recovery percentage values ranged between $99.18-101.59 \%$ for both the drugs and are close to $100 \%$ indicating that the recovery was good, and that the co-formulated substance did not interfere in the determination. The results of recovery study are summarized in Table 5. 


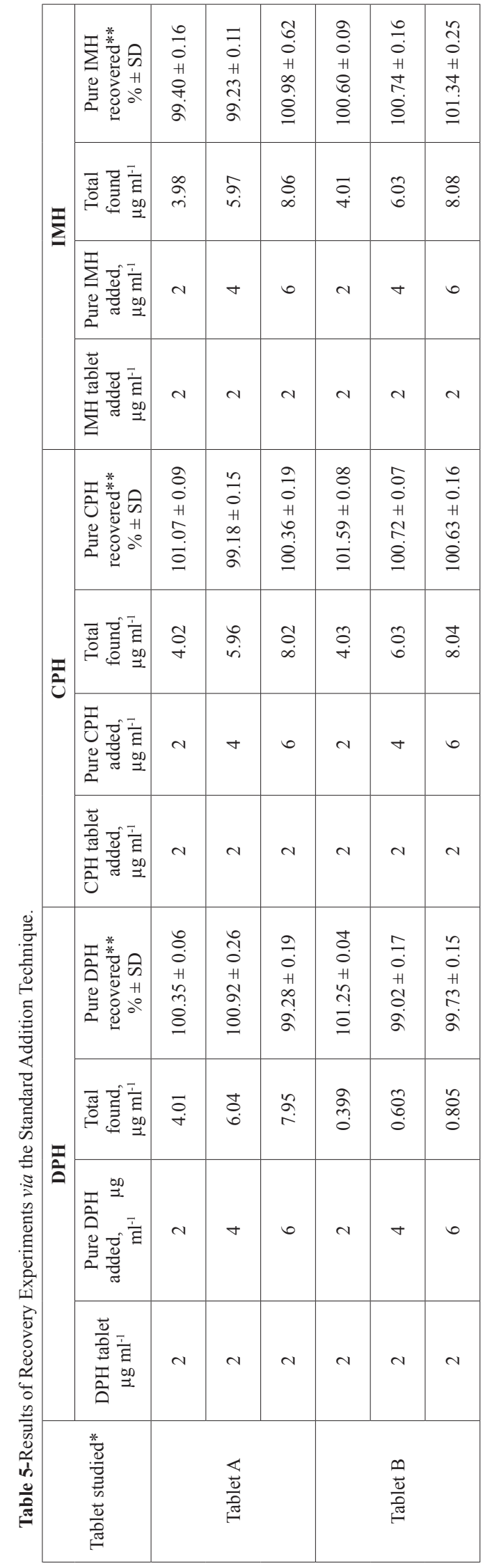

\section{CONCLUSIONS}

In the present investigation a simple, highly sensitive, accurate and precise spectrophotometric method for the routine estimation of DPH, CPH and IMH in pure form and in dosage forms is described. The method developed does not involve multi steps and do not take more operator time and expensive experimental set up like chromatographic methods. Moreover, the proposed method is free from the usual analytical complications like extraction steps [16$17,26]$ or heating [18] or cooling to 0 to $5^{\circ} \mathrm{C}[19]$, and free from interference by common additives and excipients. Further, the proposed method using EBBRbromate bromide mixture as reagent can be applied at ambient temperature and color development is instantaneous. Another advantage of the developed method is more sensitive than the reported spectrofluorometric [16] and spectrophotometric methods [16-17, 23-26]. In addition, organic solvents [16$17,20,22,25-27]$ are not used in the determination. These advantages give the proposed method a great value and make it applicable for the analysis of DPH and $\mathrm{CPH}$ in routine quality control pharmaceutical laboratories.

\section{ACKNOWLEDGEMENTS}

The authors are grateful to La Pharma, Ahmedabad, Gujarat and Aventis Pharma Ltd., Mumbai, India, for the generous supply of pure drug sample. One of the authors HND is thankful to the University of Mysore, Mysore for providing necessary facilities.

\section{REFERENCES}

1. R. Insel, J. Zohar H.Y. Meltzer (Ed.), Psychopharmacology: The Third Generation of Progress, Raven Press, New York, pp. 1205, (1987).

2. J. Zohar, T.R. Insel, Journal of Affective Disorders, 13, pp. 193, (1987).

3. P. Thoren, M. Asberg, L. Bertilsson, B. Mellstrom, F. Sjoqvist, L. Traskman, Arch. Gen. Psychiatry 37, 1289, (1980).

4. European pharmacopeia, 5.0, 1328, (2005).

5. European Pharmacopoeia, 5.0, 1395, (2005).

6. European pharmacopeia, 5.0, p. 1792, (2005).

7. M. Wozniakiewicz, J. Kuczara, P. Kooecielniak, Problems of Forensic Sciences, 69, 90, (2007).

8. C. Xiong, J. Ruan, Y. Cai, Y. Tang, J. Pharm. Biomed. Anal. 49, 572, (2009).

9. S.K. Patel, N.J. Patel, J. AOAC Int. 93, 904, (2010).

10. F. Dorrity, M. Linnolla, R.L. Habig, Clin. Chem. 23,1326, (1977).

11. B.A. Way, D. Stickle, M.E. Mitchell, J.W. Koenig, J. Turk, J. Anal. Toxicol. 22, 374, 1998.

12. F. Pommier, A. Sioufi, J. Godbillon, J. Chromatogr. B Biomed. Sci. Appl. 703, 147, (1997).

13. Y. Sasaki, S. Baba, J. Chromatogr. 426, 93, (1988).

14. G.M. Greenway, J.L. Sarah Dolman, Analyst, 124, 759, (1999).

15. F. Huang, S. Qu, S. Zhang, B. Liu, J. Kong, Microchim. Acta 161, 149 (2008).

16. N. Rahman, N. Afaq, Anal. Methods 2, 513, (2010).

17. H.M. Elqudaby, E.Y.Z. Frag, G.M. Gehad, M.A. Mohamed, Int. J. Res. Ayur. Pharm. 3, 537, (2012).

18. N.G. Keshavachar, A. Syeda, M.A. Pasha, A.A. Syed, Indian J. Pharm. Sci. 67, 175, (2005).

19. P. Nagaraja, M.F. Silwadi, A.A. Syed, Anal. Lett. 33, 2913, (2000).

20. P. Nagaraja, M. Fawaz Silwadi, S.A. Ahmed, Mikrochim. Acta, 135, 185, (2000).

21. W. Misiuk, J. Pharm. Biomed. Anal. 22, 189, (2000).

22. J.M.G. Fraga, A.I.J. Abizanda, F.J. Moreno, J.J. Arias Leon, J. Pharm. Biomed. Anal. 9, 109, (1991).

23. T. Perez-Ruiz, C. Martinez-Lozano, A. Sanz, C. Alonso, Talanta 41, 1523, (1994).

24. B. Starczewska, J. Pharm. Biomed. Anal. 23, 383, (2000).

25. B.A. El Zeany, A.A. Moustafa, N.F. Farid, J. Pharm. Biomed. Anal. 33 $775,(2003)$

26. G.N Reddy, C. Ramesh, T.V. Narayana, K.V.S. Prasada Rao, B. Ganga Rao, Int. J. Chem. Sci. 9, 457, (2011).

27. S.A. Hussein, A.M.I. Mohamed, H.Y. Hassan, Talanta 36, 1147, (1989).

28. Royal Society of Chemistry Analytical Division North West Region Schools Analyst Competition $19^{\text {th }}$ April 2005, Experimental Handbook Adran Cemeg (2005), Department of Chemistry, Prifysgol Cymru - University of Wales, Bangor.

29. International Conference On Harmonization of Technical Requirements 
for Registration of Pharmaceuticals for Human Use, ICH Harmonised Tripartite Guideline, Validation Analytical Procedures: Text and Methodology Q2(R 1), Complementary Guideline on Methodology, dated 06 November 1996, incorporated in November (2005) London.
30. H. Zavis, D. Ludvik, K. Milan, S. Liadidlaw, V. Frantisk, "Handbook of Organic Reagents in Inorganic Anaslysis", (Eds: University of Aberdem, Ellis Horwood Limited), John Wiley \& Sons IC: New York, London, Sydney, Toronto, pp. 364, (1976). 